\title{
CHEMICAL COMPOSITION OF CASSAVA FLOUR AND ITS EFFECT ON PRODUCED BALADY BREAD
}

\author{
ALI, R. GOMAA \\ Food Technology Research Institute, ARC, Giza \\ (Manuscript received 13 December 2011)
}

\begin{abstract}
This work was carried out to study the chemical, technological and sensory evaluation tests of bread making from wheat flour (82\% extr.) and its blends with 5, 10, 15 , and 20\% cassava flour. Chemical study indicated that, wheat flour contained higher amount of protein $(13.66 \%)$ and fat $(1.80 \%)$ than cassava flour $(3.29 \%$ and $1.28 \%)$, respectively. Meanwhile cassava flour contained higher amount of ash (5.44\%), crude fiber (3.70\%) and total carbohydrates $(86.30 \%)$ compared with wheat flour, which were $1.20 \%, 1.29 \%$ and $82.05 \%$, respectively. Concerning minerals, cassava flour has higher contents of $\mathrm{Ca}$, $\mathrm{Na}$ compared with wheat flour ( 252.14 vs 48.22 and 131.11 vs $96.40 \mathrm{mg} / 100 \mathrm{~g}$ sample) meanwhile $\mathrm{Mg}, \mathrm{Zn}$, and Fe decreased in cassava flour then wheat flour .Due to addition of cassava flour to wheat flour with $5.10 .15,20 \%$, the protein, fat decreased, meanwhile ash, crude fiber and total carbohydrates increased by increasing level of cassava addition in produced bread. Acceptability tests (sensory evaluation) indicated that, the wheat bread (control) has the highest total scores $(93.5 \%)$, while at $5,10,15$, and $20 \%$ cassava addition, total score was $85.0 \%, 82.0 \%, 75.5$ and 68.0 respectively. Mentioned data clear that we can produce balady bread from wheat flour (82\% ext.) blended with cassava flour at ratio up to $15 \%$ with high technological quality and acceptability.
\end{abstract}

Key words: Cassava flour, chemical composition, starch granules, mineral content, sensory evaluation, wheat flour.

\section{INTRODUCTION}

Cassava is a dicotyledonous plant belonging to the botanical family Euphorbiaceae (Schulthness et. al., 2004). Cassava is generally called Manihot esculenta crantz (synonymous with Manihot utilissima, Oboh and Elusiyan 2007). Cassava is not a cereal but a tuber. Its originated from North-East Brazil, South America). Its is now grown in Indonesia, Malaysia, Philippines, Thailand and parts of Africa including Nigeria that has recently become the world's greatest producer of cassava (leotard et. al., 2009). Cassava grows on most soils but best in light to medium loams which facilitate tuber development and harvesting. Cassava extracts less nitrogen and phosphates than most other crops but has a high demand for potassium (K) and roots are well developed to take up sulfur and zinc (Rasper and Coursey, 1967). The high content of hydrogen cyanide in cassava has been a source 
of concern because of its toxicity, Ayenor (1985) reported that the cyanide reduction to about $98.6 \%$ in the roots of cassava by retting and sun drying. Also grinding and fermentation have been reported to achieve the highest rate of detoxification of cassava food resulting in HCN reduction by over 90\% (Kent 1980). Cassava is known as a source of starch and staple food where it is eaten as fufu or garri. It has been applied in making some kinds of cakes and biscuits. Its industrial application as a source of starch and gums are well known (FAO 2010). Also, its flour has been applied for bread making (Rasper and Coursey, 1967). Consisting of 30-40 percent dry matter, the roots contains mostly, carbohydrates, but it is also rich vitamin C, carotens, calcium and potassium though poor in protein.

Palomar et. al. (1981) declared that, cassava flour has almost similar chemical composition as wheat flour except for protein (2.08\% vs $14.78 \%)$ and crude fibers (2.24\% vs $0.51 \%$ ), Ciacco and D'Appolonia (1978 b) indicated that , from 5 to $15 \%$ of the tuber flour (cassava and yam) may be substituted for wheat flour without serious detrimental effect on bread quality. They observed that, loaf volume decreased as the percentage of tuber in the blends increased. Moreover they indicated that, as the percentage of cassava flour or yam flour increased the bread crust color increased in darkness. They added that, the darkening effect was due to the higher sugars content in cassava and yam compared with wheat flour. Besides the dark crust color obtained, flour of cassava and yam improved the appearance of French-Type bread whereas it was detrimental to the white pan bread.

This work was carried out to evaluate the optimum ratios of cassava flour, which must be blended with wheat flour ( $82 \%$ extraction) to obtain balady bread with high technological qualities and good acceptance.

\section{MATERIALS AND METHODS}

\section{Materials:}

Wheat kernels (Triticum aestivum var:Sids 1 ) were obtained from Field Crops Research Institute, Agric. Res. Center, Giza, Egypt, while cassava tuber (Manihot esculent, Nigerian variety) were obtained from Ismailia Research station, Agriculture Research Center, Egypt.

\section{Methods:}

Wheat kernels were cleaned, conditioned at $14 \%$ moisture content ( $24 \mathrm{hrs}$ period), then milled on Quadrimat Senior Laboratory mill. The extraction rate was $82 \%$ for wheat flour. The flour was stored at $35^{\circ} \mathrm{C}$ in air tight contained through this study. Also cassava tubers were washed under tap water, handly peeled, cut into fin 
slices, sun dried for 10 days and grinded by Brabender whole meal miller (laboratory mill), sieved at 40 mesh to obtain cassava flour. Cassava flour was stored at $3-5{ }^{\circ} \mathrm{C}$ in air tight containers through this study. Wheat/cassava flour blends were prepared by substituted wheat flour by $5,10,15,20 \%$ cassava flour. These blends separately stored at the above mentioned condition through this study.

\section{Analytical methods:}

Protein, fats, crude fiber and ash were determined according to the AOAC (1990) procedures. Total carbohydrates were calculated by differences. Minerals were determined according to AOAC (2000). Na, Mg, Ca, Zn, Mn, Fe of different samples (flour or bread) using Perkin-Elmer Atomic absorption spectrophotometer 2380 as described in AOAC (1990).

\section{Balady bread making}

Balady bread was prepared from wheat flour (control) and wheat flour substituted separately with 5, 10, 15, and $20 \%$ cassava flour. Flour sample was mixed with other ingredient including $1 \mathrm{gm}$ compressed yeat, $1 \mathrm{gm}$ sodium chloride and adequate amount of water. The mixture was will mixed in mixer (250 rpm) for $20 \mathrm{~min}$. and the dough was left for fermentation at $30{ }^{\circ} \mathrm{C}$ and $85 \%$ relative humidity for 15 min. After fermentation, the dough was moulded on a wooden board previously covered with a thin layer of bran and left to ferment about 15 min., at the same mentioned temperature and relative humidity. The fermented dough pieces were flattened to about $20 \mathrm{~cm}$ diameter. The flattened loaves were proofed at $30^{\circ} \mathrm{C}$ and $85 \%$ relative humidity for one hour, then baked at $450-500{ }^{\circ} \mathrm{C}$ for $1-2 \mathrm{~min}$. in electric oven. After baking, bread loaves were allowed to cool in racks for about one hour before physically and organoleptically evaluation (Atia. 1986).

\section{Sensory evaluation:}

Bread quality parameters were evaluated for layer separation (20), crust color (10), crumb color (15), crumb distribution (15), odor (20), anad taste (20) were evaluated by well trained panelists in FTRI as described by Atia (1986).

\section{Microscopic examination of starch granules:}

Examination of starch granules (rupture and unruptured were carried out in upper and lower layer of the loaf of each treatment) was conducted by the method of Kongo red staining (Roy and Whulther, 1964).

Statistical analysis:

Data of sensory evaluation were analyzed by Analysis of Variance using General Linear Model (GLM) procedure within a package program of Statistical Analysis System (SAS, 1987). 


\section{RESULTS AND DISCUSSION}

From Table (1), it is clear that wheat flour (82\% ext.) contains higher percentage of protein and fat compared with cassava flour (13.66\% vs 3,29\%) and $(1.80 \%$ vs $1.28 \%)$, respectively, meanwhile cassava flour contains higher percentages of ash, crude fiber and total carbohydrates compared with wheat flour $(5.44 \%$ vs $1.20 \%),(3.70 \%$ vs $1.29 \%)$ and $(86.29 \%$ vs $82.05 \%)$ respectively. Concerning minerals it was found that the wheat flour is higher in magnesium, manganese, zinc and iron than cassava flour $(130.23,2.60,2.26$ and $7.71 \mathrm{mg} / 100 \mathrm{gm}$ vs $53.44,0.92$, 0.83 and $0.94 \mathrm{mg} / 100 \mathrm{gm}$ respectively). Meanwhile cassava flour has higher amount of sodium and calcium than wheat flour ( 131.11 and 252.17 vs 96.40 and $48.22 \mathrm{mg} / 100$ $\mathrm{gm}$ respectively. From the above mentioned data the addition of cassava flour to wheat flour $82 \%$ ext. increased sodium content which has very important role in the human body whereas it regulates heart beats and distribution of blood over all the body organs. Meanwhile cassava resulted in calcium amounted in five folds as that of wheat blends. However, supplementation of cassava flour to wheat flour resulted in $\mathrm{Na}$ and $\mathrm{Ca}$ content more than wheat flour only which are very important elements to human body especially bones and the whole skeleton of body as well as improving muscles. The obtained data are in line with those reported by Ciacco and D'Appolonia (1978 a) and Mobarak (1995).

Data in Table (2) showed that wheat flour blended with the cassava flour caused a decrease in both protein and fat contents due to increasing cassava flour level, while, fiber, ash and total carbohydrates contents were increased in the produced bread. From the same table, there is an increase in both sodium and calcium owing to the increase in cassava flour addition to wheat flour. On the other hand, cassava substitution decreased the magnesium, zinc, manganese and iron contents in the produced bread in parallel with increasing substitution rate. These results are in line with the data reported by Khurshid (1990) and Mobarak (1995).

Table (3) show distribution of ruptured and unruptured of starch granules in upper and lower layer of bread produced from wheat flour only or wheat flour supplemented with 5-20\% cassava flour. Microscopic examination obviously cleared that increasing cassava levels resulted in unruptured granules of starch resulted in both upper and lower layer, meanwhile the ruptured granules are decreased. This may be due to the high content of amylopectin in cassava flour which lead to produce dough with high viscosity and bread with high refreshment. Similar results are in accordance by those reported by Mobarak (1995) and Defloor et. al. (1995). 
Table 1. Chemical composition and mineral content of wheat flour ( $82 \%$ extraction) and cassava flour (on dry weight basis)

\begin{tabular}{|c|c|c|c|c|c|c|c|c|c|c|c|}
\hline \multirow{2}{*}{$\begin{array}{l}\text { Tested } \\
\text { samples }\end{array}$} & \multicolumn{5}{|c|}{ Chemical composition \% } & \multicolumn{6}{|c|}{$\begin{array}{l}\text { Mineral content } \\
\quad(\mathrm{mg} / 100 \mathrm{~g})\end{array}$} \\
\hline & Protein & Fat & Ash & $\begin{array}{l}\text { Crude } \\
\text { fiber }\end{array}$ & Total carbohydrates & $\mathrm{Na}$ & $\mathrm{Mg}$ & $\mathrm{Ca}$ & $\mathrm{Zn}$ & $\mathrm{Mn}$ & $\mathrm{Fe}$ \\
\hline Wheat flour & 13.66 & 1,80 & 1.20 & 1.29 & 82.05 & 96.40 & 130.23 & 48.22 & 2.26 & 2.60 & 7.71 \\
\hline Cassava flour & 3.29 & 1.28 & 5.44 & 3.70 & 86.29 & 131.11 & 53.44 & 252.17 & 0.83 & 0.92 & 0.94 \\
\hline
\end{tabular}


Table 2. Chemical composition and mineral content of balady bread produced from wheat/cassava flour blends

\begin{tabular}{|c|c|c|c|c|c|c|c|c|c|c|c|}
\hline \multirow{2}{*}{$\begin{array}{l}\text { Balady bread } \\
\text { produced from : }\end{array}$} & \multicolumn{5}{|c|}{ Chemical composition \% } & \multicolumn{6}{|c|}{$\begin{array}{l}\text { Mineral content } \\
(\mathrm{mg} / 100 \mathrm{~g})\end{array}$} \\
\hline & Protein & Fat & Ash & $\begin{array}{l}\text { Crude } \\
\text { fiber }\end{array}$ & Total carbohydrates & $\mathrm{Na}$ & $\mathrm{Mg}$ & $\mathrm{Ca}$ & $\mathrm{Zn}$ & $\mathrm{Mn}$ & $\mathrm{Fe}$ \\
\hline $\begin{array}{l}\text { Wheat flour } \\
\text { (W.F) }\end{array}$ & 14.25 & 2.00 & 1.58 & 1.64 & 79.20 & 105.50 & 136.10 & 53.98 & 2.58 & 3.30 & 8.10 \\
\hline $\begin{array}{l}\text { W.F. }+5 \% \\
\text { cassava flour }\end{array}$ & 13.71 & 1.86 & 1.88 & 1.71 & 80.28 & 107.19 & 131.66 & 58.60 & 2.47 & 5.92 & 7.70 \\
\hline $\begin{array}{l}\text { W.F. + 10\% } \\
\text { cassava flour }\end{array}$ & 13.18 & 1.70 & 2.08 & 1.80 & 81.68 & 109.93 & 127.40 & 63.74 & 2.36 & 3.09 & 7.43 \\
\hline $\begin{array}{l}\text { W.F. }+15 \% \\
\text { cassava flour }\end{array}$ & 12.27 & 1.55 & 2.23 & 1.86 & 80.75 & 112.09 & 122.15 & 68.59 & 2.26 & 2.95 & 7.06 \\
\hline $\begin{array}{l}\text { W.F. }+20 \% \\
\text { cassava flour }\end{array}$ & 12.18 & 1.40 & 2.56 & 1.96 & 81.04 & 117.44 & 95.27 & 74.44 & 2.10 & 2.90 & 6.76 \\
\hline
\end{tabular}


Table 3. Distribution of starch granules in the bread loaf after microscopic examination.

\begin{tabular}{|c|c|c|c|c|}
\hline \multirow{2}{*}{ Balady bread produced from: } & \multicolumn{4}{|c|}{ Bread loaf } \\
\cline { 2 - 5 } & \multicolumn{2}{|c|}{ Upper layer } & \multicolumn{2}{|c|}{ Lower layer } \\
\cline { 2 - 5 } & Ruptured (\%) & Unruptured(\%) & 70 & 30 \\
\hline Wheat flour (W.F) & 85 & 15 & 25 & 75 \\
\hline W.F. $+5 \%$ cassava flour & 20 & 80 & 7 & 93 \\
\hline W.F. $+10 \%$ cassava flour & 6 & 94 & 3 & 97 \\
\hline W.F. $+15 \%$ cassava flour & 1.5 & 98.5 & 1 & 99 \\
\hline W.F. $+20 \%$ cassava flour & 1 & 99 & & 7 \\
\hline
\end{tabular}


Table 4. Sensory evaluation of balady bread produced from wheat and wheat/cassava blends.

\begin{tabular}{|c|c|c|c|c|c|c|c|}
\hline \multirow{2}{*}{$\begin{array}{c}\text { Balady bread produced } \\
\text { from: }\end{array}$} & $\begin{array}{c}\text { Layer } \\
\text { separation }\end{array}$ & Crust color & Crumb color & $\begin{array}{c}\text { Crumb } \\
\text { distribution }\end{array}$ & Odor & Taste & Total score \\
\cline { 2 - 8 } & 20 & 10 & 15 & 15 & 20 & 20 & 100 \\
\hline Wheat flour (W.F) & $19.5 \mathrm{a}$ & $9.5 \mathrm{a}$ & $14.0 \mathrm{a}$ & $14.5 \mathrm{a}$ & $18.0 \mathrm{a}$ & $93.5 \mathrm{a}$ \\
\hline W.F. + $\%$ cassava flour & $16.5 \mathrm{~b}$ & $8.0 \mathrm{ab}$ & $13.0 \mathrm{ab}$ & $13.0 \mathrm{ab}$ & $17.5 \mathrm{a}$ & $17.0 \mathrm{ab}$ & $85.0 \mathrm{ab}$ \\
\hline W.F. + 10\% cassava flour & $15.0 \mathrm{~b}$ & $7.5 \mathrm{~b}$ & $12.5 \mathrm{abc}$ & $13.0 \mathrm{ab}$ & $17.0 \mathrm{a}$ & $17.0 \mathrm{ab}$ & $82.0 \mathrm{bc}$ \\
\hline W.F. $+15 \%$ cassava flour & $14.5 \mathrm{bc}$ & $7.0 \mathrm{~b}$ & $12.0 \mathrm{bc}$ & $12.0 \mathrm{~b}$ & $14.0 \mathrm{~b}$ & $16.0 \mathrm{ab}$ & $75.5 \mathrm{c}$ \\
\hline W.F. + 20\% cassava flour & $13.0 \mathrm{c}$ & $6.0 \mathrm{~b}$ & $11.0 \mathrm{bc}$ & $10.0 \mathrm{c}$ & $13.0 \mathrm{~b}$ & $15.0 \mathrm{~b}$ & $68.0 \mathrm{~d}$ \\
\hline L.S.D. & 1.9379 & 1.886 & 1.6773 & 1.6773 & 1.6773 & 6.8233 & 9.1722 \\
\hline
\end{tabular}


Table (4) declared the sensory evaluation of wheat bread and that supplemented with 5-20\% cassava flour. It was found that addition of 5, 10, 15 and $20 \%$ cassava flour to wheat flour caused gradual decrease in the values of sensory evaluation tests (layer separation, crust color, crumb color, crumb distribution, odor and taste), which reflected on total score of sensory evaluation which showed total score of evaluation $85,82,75.5$, and $68 \%$ due to supplementation level of cassava flour compared with the total score of wheat bread (93\%).

The results in Table(4) indicated that at 5 and $10 \%$ substitution levels produced balady bread with good sensory evaluation parameters which remarkably differ than the control, while addition of $20 \%$ cassava to wheat flour caused an adverse effect on baking and sensory evaluation quality.

Conclusion:

From the abovementioned data, it could be recommended that, balady bread characterized with high technological and sensory evaluation could be produced by supplemented wheat flour $82 \%$ ext. with about $5-10 \%$ of cassava flour.

\section{REFERENCES}

1. A.O.A.C. 2000. Official methods of analysis $\left(17^{\text {th }}\right.$ ed) Association of Official Analytical Chemists. Washington. D.C.

2. Atia, A. A. 1986. Physical and chemical studies on staling on some Egyptian bread. Ph.D. thesis, Fac. Agric. Cairo University.

3. Ayenor, G. A. 1985. Effect of retting of cassava on product yield and cyanide detoxification. J. Food .Technol. 20: 89-96>

4. Ciacco, C. F. and D'Appolonia. 1978 a. Baking studies with cassava and yam flour. I- Biochemical composition of cassava and yam flour. Cereal Chem. 55(3):402-411

5. Ciacco, C. F. and D'Appolonia. 1978 b. baking studies with cassava and yam flour. II- Rheological and baking studies of tuber-wheat flour blends. Cereal Chem. 55(4):423-435.

6. Defloor, I., R. LeiJskens, M. Bokanga and J. A. Delcour. 1995. Impact of genotype crop age and planting season on the bread making and gelatinization properties of cassava (Manihot esculenta crantz) flour. Journal Article. J. Sci. of Food and Agriculture. 68(2): 167-174.

7. FAO. 2010. Cassava processing: utilization of cassava products, food and Agriculture Organization of the United Nations Corporate Document.Repository. http://www.fao.org/docrep/x5032e/x5032eo6.htm. 
8. Kent, J. 1980. detoxification of cassava regal handbook of industrial chemistry, Van Nostrand and co. New York. Pp.663.

9. Khurshid, K.M. 1990. Evaluation of some green forages with special reference to their nutritive values. Ph.D. thesis , Faculty of Agric.. Zagazig University, Egypt.

10. Leotard, G., A. Deputie , J. Graville, E. Douzery , C. Debam and D. Mckey. 2009. Phylogeography and origin of cassava: new insight from the northern rim of the Amazonian basin. Mol. Phylogenet. Evol. 53: 329-334.

11. Mobarak, E. A. 1995. Technological studis on some cereal products. M.Sc. thesis, Faculty of Agric., Zagazig University, Egypt.

12. Oboh, G. and C. A. Elusiyan. 2007. changes in nutrient and anti-nutrient of micro-fungi fermented cassava flour produced from low and medium cyanide variety cassava tubers. Afr. J. Biotechnol. 6:2150-2157.

13. Palomar, L. S., J. A. Prez and G. L. Pascual. 1981. Wheat flour substitution using sweet potato or cassava in some bread and snack items. Visayas state coll of agric. Bayboy, Leyte Philippines of Tropical Research, Vol.3, No.1, P.817.

14. Rasper, V and D. G. Coursey. 1967. Properties of starches of some West African yam. J. Sci. Food. Agric. 18:240-244.

15. Roy, L. Whulther. 1964. Methods in carbohydrate chemistry. Vol IV. Starch N.Y. and London.

16. SAS. 1987. SAS propriety software. Statistical Analysis Institute Inc. Cary, North Carolina, U.S.A.

17. Schultness, F., A. Chabi-Olaye and S. Gounou. 2004. Multitrophic levels interactions in a cassava-maize mixed cropping system in the humid tropics of west Africa. Bull. Entomol Res. 94:261-272 
التركيب الكيميائى لاقيق الكسافا وأثره على الخبز البلدى الناتج

$$
\text { رفاعى جمعة على }
$$

$$
\text { معهُ بحوث تكنولوجيا الأغذية - مركز البحوث الزراعية ـ الجيزة }
$$

فى هذا البحث تم در اسة التركيب الكيماوى و الخواص التكنولوجية و الإختبـار ات الحسية للدقيق القمح ، الكسافا و الخبز البلاى المكون من دقيق القمح ( استخلاص 82\%) مضــافا اليه 5، 10، 15،

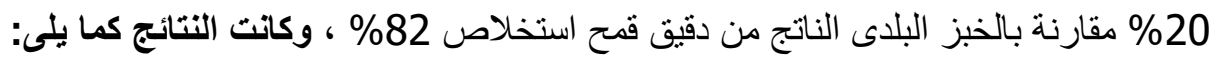

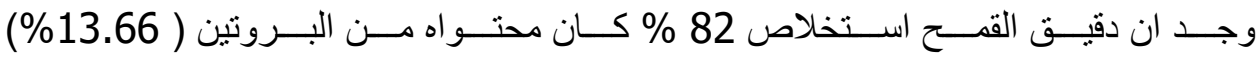

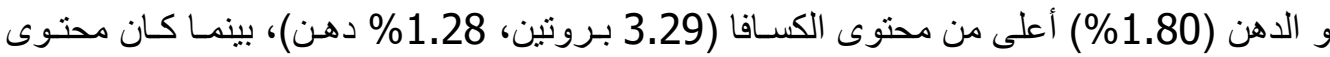

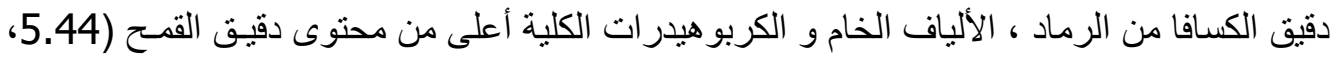

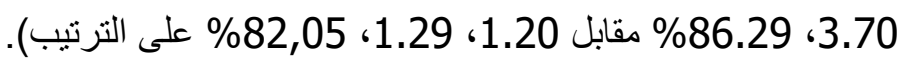
وجد أن محتوى دقيق الكسافا من الكالسيوم ، الصوديوم أعلى من محتوى دقيق القمح (132.17

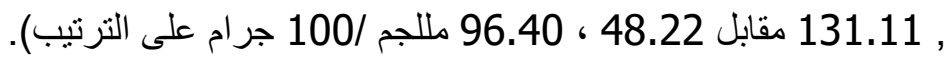
وجد من التحليل الكيماوى للخبز الناتج أن إضافة دقيق الكسافا الى دقيق القهـح بنسـب 5 ، 10،

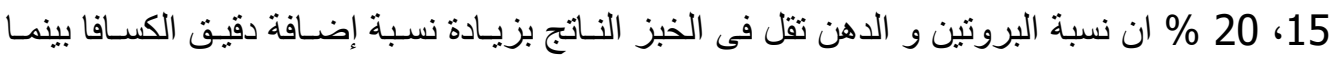

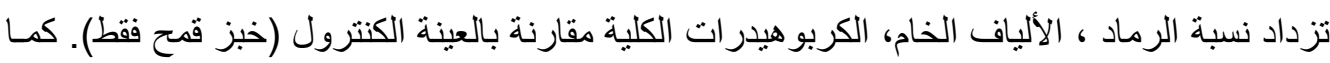

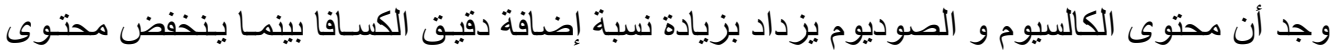
الماغنسيوم و الزنك و الحديد مقارنة بالعينة الكنترول. أظهرت الإختبار ات الحسية أن الخبز الناتج من دقيق القمح (الكنترول)حساز على أعلى أعلى درجـات

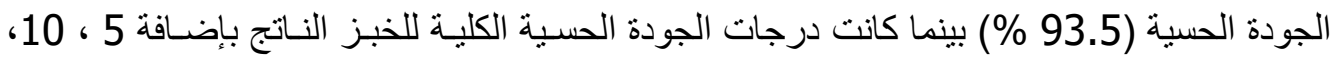
15، 20\% دقيق كسافا 85، 82، 75.5 ، 68 \% \%

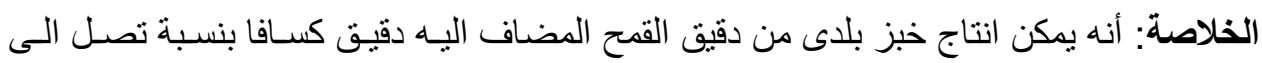
15\% دون تأثثير ضار على الجودة الكيماوية و التكنولوجية و الحسية للخبز الناتج. 